\title{
Research on Junior High School English Reading Class Based on the Principle of Timing and Thorndike's Three Laws of Learning
}

\author{
Yefan Ni \\ Zhejiang Ocean University, Zhoushan, China \\ Jingjing Lu \\ Zhejiang Ocean University, Zhoushan, China
}

\begin{abstract}
Thorndike was a famous American psychologist in the early 20th century. Based on the hungry cat box experiment, he proposed three famous learning laws in 1911: The Law of Readiness, the Law of Exercise and the Law of Effect. With the reform of contemporary education -- the rise of quality-oriented education and the popularity of task-based teaching, Thorndike's three Laws of Learning have played an important theoretical support for our contemporary research. At the same time, we also see a huge research prospect and correlation between educational psychology and English teaching methods. This paper intends to study the efficiency and interesting teaching of a junior English reading class, and solve the research problems caused by the combination of Thorndike's three Laws of Learning and the principle of timing. By using the methods of questionnaires and interview, the author collected the effective data and information concerning high efficiency and interesting learning in junior high school English reading class.
\end{abstract}

Index Terms - Thorndike's three laws of learning, the principle of timing, teaching reading

\section{INTRODUCTION}

Nowadays, in the 21st century, with the development of task-based teaching method and increasing popularity of well-rounded education, many theories in educational psychology were found to apply in our teaching class of junior high school. These theories have large research prospect, which can enlighten today's English teaching. What's more, the ultimate aim of educational psychology research is to put into practice, proving the effectiveness on the theory, and to give teachers some instructions and inspirations, combining with teaching methodology. However, the researches to put these theories into English learning class of junior high school seems scarce, let alone Thorndike's Three Law of Learning. This study will focus on providing efficient and interesting inspiration, as well as the adjustment between actual teaching and students' expectations for today's junior high school English reading classes, combining Thorndike's Three Laws of Learning with the principle of timing, according to relevant theories and students' actual expectations. Thorndike's Three Laws of Learning own great research value. And the principle of timing is not just one aspect, but need to run through the whole English class, which should be included in teaching rhythm, teaching instruction, feedback, etc. Combining the two, the scope of the research can be more extensive and the content of the research is more substantial. It is hoped that the author's research will be helpful to the teaching of English reading class in junior middle school.

\section{THE BACKGROUND OF STUDY}

\section{A. Thorndike's Three Laws of Learning}

Thorndike is the first American psychologist to systematically discuss educational psychology, who did pioneering work in many areas of education. By the end of the 19th century, Thorndike was conducting a number of animal experiments. The most famous of these was an experiment in which the hungry cat learned how to get food out of their cages. In addition, based on these experiments, Thorndike proposed three laws: Law of Readiness, Law of Exercise, and Law of Effect. Although these theories maintain some flaws, there is still much worth studying.

Thorndike's Three Laws of Learning cover many fields. Nevin (1999) applied the law of effect in the notion of a bond in chemistry area to conclude that the magnitude of satisfaction is consistent with current research on resistance to change. Santos (2018) found that as behaviors that lead to reinforcement tend to be repeated more often, the neural activity patterns that lead to reinforcement are re-entered more frequently based on the law of effect. The problems can be that no researcher is involved in the field of teaching, and the amount of research has been decreasing since the $21 \mathrm{st}$ century.

It is worth mentioning that, in China, there are many researches and applications of Thorndike's Three Laws of Learning in teaching. Lihua Fang (2011) pointed out the significance of Thorndike's Three Laws of Learning and gave 
some ideas on English teaching. What's more, Shuzhi Geng (2013) echoed the idea of that we need to pay more attention to Thorndike's Three Laws of Learning and put forward some enlightenment. There are still some essays discussing about the English teaching, combined with the three laws. We can see that Thorndike's Three Laws of Learning can shine in the teaching field, and combined with the teaching methodology will be more helpful for teaching.

\section{B. Law of Readiness with Principle of Timing - Good Preparation and Motivation}

With the combination of Law of Readiness and principle of timing, if students are well prepared, they can fully participate in activities in class, and they will be satisfied. Instead, when students are well prepared but there are no activities, they will feel anxious. In addition, no preparation and compulsive activities will make students anxious, too (Chen \& Liu, 2018). In addition, Thorndike's preparation is the preparation of motivation (Ma, 2001). It can be proved that the preparation of motivation is significant. Harmer (1998) pointed out some causes of motivation and reported that motivation plays an indispensable role in starting a class.

With the principle of time, we need to generate the motivation before class, which is called "preview". Considered the interest and the efficiency in class, teachers should design pre-class tasks and activities carefully. Miaoying Chen (2020) concludes some rough suggestions about how to preview, which inspire me to put the theory into practice.

\section{Law of Exercise with Principle of Timing-Exercise in Class and after Class}

With the combination of Law of Exercise and principle of timing, the repetition of a learned response will enhance the stimulus-response connection, known as the S-R connection. The more the connection is practiced and used, the stronger it becomes. Instead, it gets weaker (Chen \& Liu, 2018). Combined the principle of timing, repeated and timely practice, not only during the class but also after the class, can improve the efficiency of reading classes and students' interest in learning. The problem is how to order the activities during the class and the homework after class. Xinli Cha (2017) explains disadvantages of current practice and design strategies and gives some tips on how to overcome them.

\section{Law of Effect with Principle of Timing-Error Correction}

With the combination of Law of Effect and principle of timing, Qi Chen and Rude Liu (2018) gives the concrete explanation about Law of Effect that behaviors which produce satisfying results in a given situation tend to occur repeatedly in that situation. In a situation where an action is followed by a satisfactory change, the likelihood of the action being repeated in a similar situation increases. If not, it will be less likely. Therefore, combined with principle of timing and English reading class, we need to focus on the error correction in class and our correction should be timely.

As for the error correction, Harmer (1998) first gives a comprehensible explanation of why do students make mistakes. In addition, Corder (1967) said that no matter how hard we try, there is always bias. Qiang Wang (2006) further explains how to choose the type of correction. Jingru Wang (2020) looks at more concrete interpretations in English classroom error correction study, through further research, summarizes the four principles. The above theory provides a very comprehensive basis for error correction, however, these theories did not explore one of the specific English classes, and also did not explore the current situation of error correction in junior high schools. These gaps are worthy of the further study.

\section{RESEARCH DESIGN AND FINDINGS}

\section{A. Research Objects}

This study carried out questionnaire investigation to junior high school students who accepted the new English syllabus and engaged in a certain number of reading classes. The author took 133 junior high school students as satisfactory samples from the research objects to reflect the real classroom situation and students' expectation. A total of 133 questionnaires were collected on the professional online questionnaire platform called SO JUMP. All the 133 respondents were effective subjects, and the effective rate was $100 \%$. And the 133 students came from four different classes.

\section{B. Research Methods}

At the end of April, the author established the project of "Research on Junior High School English Reading Class Based on the Principle of Timing and Thorndike's Three Laws of Learning". In order to explore the efficiency and interest of English reading class, the author sent the online questionnaire to the respondents in SO JUMP for random sample collection. The content of the questionnaire includes the students' grade information, the students' expectation of the preview activities in the reading class, the task in class and after class, as well as the teacher's feedback mechanism. The questionnaire, which lasted for one week, was completed on May 5 and was fully valid.

C. Research Results and Date Analysis 
TABLE I.

TEAChers’ ArRangement Of A ReAding Class Preview Activity (MUltiple Choices)

\begin{tabular}{|c|c|c|}
\hline & Number & Rate \\
\hline Searching Internet & 42 & $69.58 \%$ \\
\hline $\begin{array}{c}\text { Copying new words } \\
\text { and reading the text }\end{array}$ & 93 & $56.39 \%$ \\
\hline $\begin{array}{c}\text { Questions } \\
\text { in the book }\end{array}$ & 75 & $10.53 \%$ \\
\hline No arrangement & 14 & $8.27 \%$ \\
\hline Other & 11 & \\
\hline
\end{tabular}

From table 1, it is self-evident that most teachers are inclined to complete the preparation activities with closed tasks. A small number of teachers will see the importance of Internet and combine open and closed tasks together.

TABLE II.

RESPONDENTS' EXPECTATIONS OF A READING CLASS PREVIEW ACTIVITY

\begin{tabular}{|c|c|c|}
\hline & Number & Rate \\
\hline Internet & 52 & $24.81 \%$ \\
\hline $\begin{array}{c}\text { Copying new words } \\
\text { and reading the text }\end{array}$ & 33 & $30.08 \%$ \\
\hline $\begin{array}{c}\text { Questions } \\
\text { in the book }\end{array}$ & 40 & $6.02 \%$ \\
\hline Other & 8 & \\
\hline
\end{tabular}

From table 2, we can see that students' expectations are not particularly one-sided. However, the majority of students (39.10\%) still prefer to finish the preparation activities of the reading class through the Internet. Second only to the Internet, students $(30.08 \%)$ prefer to complete the reading preparation activities by combining with book thinking questions. Compared with table 1 , it is not difficult to find that students are not interested in copying new words or reading the text.

TABLE III.

TEACHERS' ARRANGEMENT OF THE OPEN QUESTIONS

\begin{tabular}{|c|c|c|}
\hline & Number & Rate \\
\hline Yes, many times & 68 & $51.12 \%$ \\
\hline Yes, some times & 57 & $42.86 \%$ \\
\hline No, they just focus on 2c-2e & 8 & $6.02 \%$ \\
\hline
\end{tabular}

TABLE IV.

RESPONDENTS’ EXPECTATIONS OF THE TYPE OF THE QUESTIONS

\begin{tabular}{|c|c|c|}
\hline & Number & Rate \\
\hline All in 2c-2e & 18 & $13.53 \%$ \\
\hline All about open questions & 10 & $5.52 \%$ \\
\hline $\begin{array}{c}\text { Combined two, } \\
\text { 2c-2e is more }\end{array}$ & 69 & $51.88 \%$ \\
\hline $\begin{array}{c}\text { Combined two, } \\
\text { open questions are more }\end{array}$ & 36 & $27.07 \%$ \\
\hline
\end{tabular}

From table 3, we can draw a conclusion that most teachers (93.98\%) will not adopt a rigid way of asking questions, so they can better inspire students to think in various aspects by asking open questions. And from table 4, most students (78.95\%) accept that the open questions should be combined with the problem sets in the book(2c-2e), but surprisingly, the majority of students prefer $2 \mathrm{c}-2 \mathrm{e}$. According to their answers about why they prefer $2 \mathrm{c}-2 \mathrm{e}$, most students are influenced by exam-oriented education, believing that it can improves their grades, involves more tests, and is easier to answer. A few students think the text can be better consolidated. We find that exam-oriented education has a greater influence on students than quality-oriented education. It should be taken seriously.

TABLE V.

WHETHER TEACHERS’ AFTER-Class TASKS ARE RELATED TO THE ACTIVITIES IN Class OR Not

\begin{tabular}{|c|c|c|}
\hline & Number & Rate \\
\hline Yes & 102 & $76.70 \%$ \\
\hline No & 31 & $23.30 \%$ \\
\hline
\end{tabular}

From table 5, most of the teachers' homework will be arranged in combination with classroom activities, and through the description of many students, such related homework will usually be presented in the form of oral output. For example, if a topic is discussed in class, the teachers will let students make up the dialogue and act it out. These are of great help to today's English reading classes. 
TABLE VI.

TEACHERs' ARRANGEMENT ON THE HOMEWORK (MULTIPLE CHOICE)

\begin{tabular}{|c|c|c|}
\hline & Number & Rate \\
\hline $\begin{array}{c}\text { Copying new words } \\
\text { or phrases }\end{array}$ & 81 & $60.90 \%$ \\
\hline Reciting the passage & 111 & $83.46 \%$ \\
\hline Oral practice & 53 & $39.85 \%$ \\
\hline $\begin{array}{c}\text { Oral practice in combination with the } \\
\text { topics discussed in class }\end{array}$ & 60 & $45.11 \%$ \\
\hline $\begin{array}{c}\text { Writing practice in combination with the } \\
\text { topics discussed in class }\end{array}$ & 46 & $34.59 \%$ \\
\hline Interesting activities & 16 & $12.03 \%$ \\
\hline Other & 8 & $6.02 \%$ \\
\hline
\end{tabular}

From table 6, many teachers like to combine closed homework with open homework when assigning homework. But in the table 9, most teachers prefer to use closed homework as the main methods (including words, passages, homework books, etc.). Although the extended exercises of oral writing are involved, they belong to the in-class types and the emphasis on interesting activities is not really high.

TABLE VII.

RESPONDENTS’ EXPECTATIONS OF HOMEWORK (MUlTIPLE CHOICE)

\begin{tabular}{|c|c|c|}
\hline & Number & Rate \\
\hline $\begin{array}{c}\text { Copying new words } \\
\text { or phrases }\end{array}$ & 69 & $51.88 \%$ \\
\hline Reciting the passage & 66 & $49.62 \%$ \\
\hline Oral practice & 65 & $48.87 \%$ \\
\hline $\begin{array}{c}\text { Oral practice in combination with the } \\
\text { topics discussed in class }\end{array}$ & 61 & $45.86 \%$ \\
\hline $\begin{array}{c}\text { Writing practice in combination with the } \\
\text { topics discussed in class }\end{array}$ & 47 & $35.34 \%$ \\
\hline Interesting activities & 73 & $54.89 \%$ \\
\hline Other & 7 & $5.26 \%$ \\
\hline
\end{tabular}

From table 7, we can see that in the context of exam-oriented education, many students want closed homework. However, according to the data, the popularity of interesting activities among students is very high, which shows that there is still a contradiction between exam-oriented education and quality-oriented education in contemporary English classes.

TABLE VIII.

TEACHERS’ REACTIONS AFTER STUDENTS’ ANSwers (Multiple CHOICE)

\begin{tabular}{|c|c|c|}
\hline & Number & Rate \\
\hline Hardly encourage us & 22 & $36.54 \%$ \\
\hline $\begin{array}{c}\text { Telling us } \\
\text { the mistake directly }\end{array}$ & 41 & $48.83 \%$ \\
\hline $\begin{array}{c}\text { After encouraging us, } \\
\text { point our mistakes }\end{array}$ & 65 & $47 \%$ \\
\hline $\begin{array}{c}\text { Telling us } \\
\text { the mistake indirectly }\end{array}$ & 63 & $47.73 \%$ \\
\hline Other & 5 & $3.76 \%$ \\
\hline
\end{tabular}

TABLE IX.

RESPONDENTS' EXPECTATIONS OF TEACHERS' REACTIONS AFTER THEIR ANSWERS (MultiPle CHOICE)

\begin{tabular}{|c|c|c|}
\hline & Number & Rate \\
\hline $\begin{array}{c}\text { wrong answer- } \\
\text { tell us mistakes directly }\end{array}$ & 32 & $24.06 \%$ \\
\hline $\begin{array}{c}\text { wrong answer- } \\
\text { give us more encourage words } \\
\begin{array}{c}\text { wrong answer- } \\
\text { encourage us with error correction } \\
\text { indirectly }\end{array}\end{array}$ & 64 & $48.12 \%$ \\
\hline $\begin{array}{c}\text { right answer- } \\
\text { encourage us }\end{array}$ & 88 & $66.17 \%$ \\
\hline $\begin{array}{c}\text { right answer- } \\
\text { not encourage us }\end{array}$ & 85 & $63.91 \%$ \\
\hline Other & 24 & $18.05 \%$ \\
\hline
\end{tabular}

From table 8, we conclude that most teachers avoid direct error correction and teach through a combination of encouragement and indirect error correction, which is worth rejoicing. However, some teachers take the way of direct error correction. This way is fast, but not conducive to the long-term growth of students.

From table 9, we find that the majority of students want to be encouraged and praised by their teachers. Even if there are mistakes in the answer, they do not want the teacher to correct directly, but through a gentle way. Through the 
combination of the two tables, it is not difficult to find that most teachers' reactions cater to students' expectations.

\section{Discussion About the Problems}

\section{A. The Conflict of Expectations between Teachers' and Students'}

According to Law of Readiness and principle of timing, we should set up preview activities before class. But there is a big difference between the arrangement of teachers and the expectation of students in the selection of previewing activities. For example, teachers tend to carry out preview activities by copying words, reading the text and combining thinking questions. But for students, they tend to use the Internet to learn more about their reading background. One is the emphasis on mechanical training; one is the emphasis on interesting activities. So, the conflict rises.

For teachers, this kind of traditional mechanical preview can better enable students to adapt to the rhythm of the class. This kind of task is simple and fixed, but lacks vitality. For students, giving full play to the role of the Internet can help them better understand more or less information. It's efficient and interesting, but requires a little more of a teacher.

\section{B. The Gap between Exam-oriented Education and Quality-oriented Education}

According to Law of Exercise and principle of timing, combined with the classroom activities and assignments assigned by teachers, the classroom activities and assignments expected by students and the reasons of students, it is not difficult to see that students hope to consolidate and practice through interesting activities on the one hand, so as to stimulate their enthusiasm and initiative for learning. But on the other hand, due to the influence of exam-oriented education, students tend to do $2 \mathrm{c}-2 \mathrm{e}$ in class, and copy words, recite texts and other mechanical activities after class, which may be helpful for exam-oriented education. However, these tasks make no sense for quality-oriented education.

The students' answers about why they are inclined to choose $2 \mathrm{c}-2 \mathrm{e}$ or some mechanical activities rather than the open questions or some interesting activities are all related to the exam-oriented education. For example, some students think that these tasks are helpful for the exam; some believe that these will improve the scores, some think that these are related to the passage they have learned, and some also hold the idea that these may be better to enhance the basic knowledge. However, we doubt that whether these tasks are helpful to students.

Meanwhile, as for the reasons why no choosing $2 \mathrm{c}-2 \mathrm{e}$, they feel that open tasks are more motivating and challenging and can expand their extracurricular knowledge, thus promoting their study. That's what quality-oriented education like. But, under the circumstance of exam-oriented education and examination pressure, how to narrow the gap between the two educational models, or on what basis can the two education models be better coordinated, is well worth studying in depth.

\section{How to Meet Students' Expectations in Terms of Feedback}

For teachers' feedback to students' answers, many teachers are concerned with what can be the best way to deal with answers from their students. There are some common situations. For example, first of all, some teachers will naturally show disgust after students answer the questions in a wrong way, but tell students that it is fine. Students will be aware of this contradictory behavior actually. Second, some teachers think that pointing out mistakes pointedly can help students improve their level to a greater extent, but ignore the importance of students' internal psychological changes. Third, some teachers believe that as long as students are encouraged, students will be proud, which are completely ignoring the relevant knowledge of educational psychology and the achievement motivation of students. So, how to meet students' expectations in terms of feedback can be a problem.

\section{SUGGESTIONS}

\section{A. Making Preview Activities Diversified}

Due to different expectations of teachers and students, imagine that if only mechanical preview activities are arranged, students will lose their enthusiasm, have low classroom efficiency and be easily distracted. On the contrary, if students are simply allowed to preview on the Internet, they will neglect classroom knowledge, use computers in a wrong way, and develop bad habits of relying on computers.

When assigning preview activities, it's suggested to follow the principle of combining Internet and mechanical activities, among which the proportion of Internet should be greater than that of mechanical activities. Teachers should pay attention to the following principles when arranging mechanical activities. First, the principle of flexibility. Some flexible and various activities should be designed to satisfy the needs of students. Second, the principle of innovation. Teachers can innovate mechanical activities and combine them with the current hot pots of the relevant course and some related information on the Internet.

What's more, teachers need to pay attention to one principle when using Internet-diversification. Teachers should look for the elements that are conducive to students' learning and play their due role through the investigation of students. According to the survey, most students $(80.77 \%)$ are inclined to video. It tells us that we can arrange some movies and documentaries which are beneficial for learning when we need to use Internet. Teachers should also have a better understanding of the plots and themes of the films they assign, so as to better sublimate students' thoughts.

\section{B. Conducting Class Activities and Homework Based on Students' Interest}


Combined with the Law of Exercise and principle of timing, the exercise should be effective and timely, as well as the exercise after class should be related to the exercise after class. So, the students' enthusiasm plays an indispensable role in the English class. Without interest, all tasks are in vain. Based on this theory, teachers should not place too much emphasis on mechanical training when designing class tasks and homework. As long as students are not willing to learn, no matter how teachers effectively code knowledge, it is not effective at all. Teachers are supposed to find ways to motivate students, not to instill knowledge in a hurry.

When teachers design the class activities, they should ensure that the activities should be related to the actual life and our topic in class. Students will lose interest in answering abstract knowledge and questions, which requires teachers to try their best to match the activities with reality.

When designing homework, teachers should consider the links to class activities and follow the principle that open homework oriented and close homework is complementary. Based on the principle, teachers should design some interesting homework which is apt to student's interest. When students complete these interesting activities, they can not only have a further understanding and consolidation of knowledge, but also indirectly improve their comprehensive English ability.

\section{Giving Encouragement Frequently}

Whether the students' answers are correct or not, teacher's first response should be encouragement. In educational psychology, reinforcement is better than punishment, especially the positive reinforcement. Learning a foreign language is strongly equipped with interest. When students get up the courage to answer the question, and then they rise the expectation that teacher should cater to, however, the teacher did not give reinforcement which can be critical, so students will soon lose confidence and motivation, and the effect of study becomes worse and worse.

Therefore, teachers should pay attention to the following points when giving feedback. First, it is easy for students to detect the teacher's expression of sincerity and consistency if teachers are not satisfied with students' answers from inner heart, but saying "It's fine" to the students. Second, before pointing out mistakes, teachers should encourage students to express their affirmation on the one hand, and maintain students' confidence and self-esteem on the other hand. Thirdly, although encouragement is an external motivation of students, students really need it. Junior high school students are more sensitive to external feedback. Teachers should try to promote students' external motivation to internal motivation through the feedback.

\section{CONCLUSION}

In this paper, the author combined Thorndike's Three Laws of Learning with the principle of time, from which we draw the conclusion in each part. First of all, according to Law of Readiness and principle of timing, because of the difference between teachers' and students' expectations, what we have to alter is to make preview activities more diversified. Single activity lasting for a long time is easy to produce the bored and tired feeling. Diversified activities can actually let the whole class more efficient and arouse students' motivation, which is beneficial to the next law. Secondly, according to Law of Exercise and principle of timing, focus on the students' interest plays an indispensable role in our teaching. As for teachers, we should design the homework linked to the classroom discussing questions, which require teachers not to skimp on convenience. Last but not least, according to Law of Effect and principle of timing, we are apt to use encouragement frequently in a suitable way. No matter the answers are true or false, what students need most is encouragement.

All in all, the combination of Thorndike's Three Laws of Learning and modern English teaching methods has a huge research and application prospect, and some changes should be made to refine the current English teaching. It is beyond doubt that utilizing the theory in English teaching can make the class more efficient and interesting.

\section{APPENDIX. QUESTIONNAIRE}

\section{初中英语阅读课堂高效性和趣味性学习问卷调查}

本问卷旨在了解各位同学对于当前初中英语阅读课堂的看法和倾向, 逐步提高英语阅读课堂的高效性和趣味 性。问卷采用匿名的方式, 题量少, 仅用于学术上的统计和分析, 感谢大家的填写。

\section{一. 你的年级是}
1) 初一
2）初二
3）初三

二. 对于预习活动, 老师通常是如何布置的 (可多选)

1) 结合互联网, 了解相关背景

3) 结合课后思考题提前熟悉课文

2) 抄写新单词、熟读课文

三. 对于预习活动, 你更希望是

4）通常不布置预习活动

5）其他

1) 结合互联网, 了解相关背景

2）抄写新单词、熟读课文

3) 结合课后思考题提前熟悉课文

4) 其他

四. 你更喜欢通过什么方式了解阅读背景（若第三题选择 1) 则出现此题）
1）观看英文电影
2）上网搜索文字资料
3）听老师口头介绍 
4）观看时间不长的纪录片（类似于：六分钟了解英国文化） 5）其他

五. 在课堂中，老师会提问开放式问题，让你们进行讨论吗
1) 会的, 次数挺多
2) 会的，不过次数不多
3 ) 不会, 基本都是讲解课后习题（2c-2e）

六. 在阅读课堂中, 对于老师的提问内容, 你更倾向于什么类型

1) 全是书中课文后的习题（2c-2e）

2) 全是开放式的讨论问题

3 ) 两者结合, 但课后习题 (2c-2e) 应多一点

4) 两者结合, 但开放式问题应多一点

七. 在英语课堂中, 对于你回答的问题, 老师通常采取什么反馈（可多选）

1）老师几乎很少说鼓励/表扬的话语 2）老师会直接告诉我, 我的错误是什么

3）老师会先鼓励我，再纠正我的错误 4）老师会委婉的纠正我的错误
八. 当你回答完老师的问题后，你希望老师能够做出什么样的反馈（多选）

1) 回答错误了, 希望直接提出我的错误, 不要鼓励

2) 回答错误了, 希望能够多点鼓励

3) 回答错误了, 希望在鼓励的同时, 能够委婉的提出错误

4）回答正确了, 希望得到表扬

5) 回答正确了, 希望不要表扬我

九. 对于阅读课堂, 老师布置的作业是否跟课上的活动有联系

1）是, 有联系 2 ) 否, 无联系

3) 无联系的作业多 4) 有联系的作业多

十. 对于阅读课堂的作业, 老师通常是如何布置的 (多选)

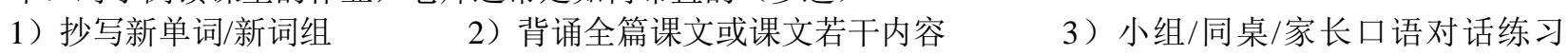

4) 会结合课上的讨论话题, 进一步进行口语练习 5) 会结合课上的讨论话题, 进一步进行写作练习

6）会结合课上的内容, 课下布置趣味性活动 7) 其他

十一. 对于阅读课堂的作业, 你希望是什么呢（多选）

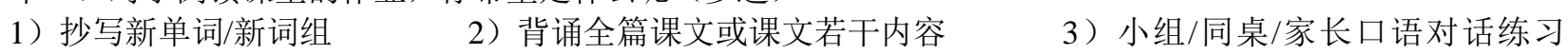

4) 会结合课上的讨论话题, 进一步进行口语练习结合课上的讨论话题, 进一步进行写作练习

6）会结合课上的内容, 课下布置趣味性活动 7) 其他

\section{REFERENCES}

[1] Cha, X.L. (2017). Strategies for Designing Junior Middle School English Homework Based on Student-Based Perspective. Electronic Journal of the New Education Era (Teacher edition) 11, 127.

[2] Chen, M.Y. (2020). A Brief Discussion on the Preparation of Junior Middle School English Reading Class. Reading and writing 2, 116.

[3] Chen, Q. \& Liu, R.D. (2018). Contemporary Educational Psychology (3rd Edition). Beijing: Beijing Normal University Press.

[4] Corder, S.P. (1967). The significance of learner's errors. International Review of Applied Linguistics 5, 161-167.

[5] Fang, L.H. (2011). Thorndike's Three Laws of Learning and Their Implications for Foreign Language Teaching. Science and Education Guide 17, 9-10.

[6] Geng, S.Z. (2013). English Teaching in Middle School Based on Connection Theory. Secondary Education Research 52, 198.

[7] Harmer, J. (1998). How to Teach English. London: Addition Wesley Longman Limited.

[8] Ma, C.H. (2001). Thorndike's Laws of Learning and Its Implications. Journal of Changshu College 3, 68-70.

[9] Nevin, J.A. (1999). Analyzing Thorndike's Law of Effect: The Question of Stimulus-Response Bonds. Journal of the Experimental Analysis of Behavior 72(3), 447-450.

[10] Santos, F.J. \& Athalye, V.R. \& Carmena, J.M. et al. (2018). Evidence for a neural law of effect. Science 359, $1024-1029$.

[11] Ur, P. (1996). A Course in Language Teaching. Cambridge: Cambridge University Press.

[12] Wang, J.R. (2020). Research on the Application of Error Correction Strategies in Junior Middle School English Teaching. China 2, 143.

[13] Wang, Q. (2006). A Course in English Language Teaching. Beijing: Higher Education Press.

[14] Yule, G. (1996). Pragmatics. Oxford: OUP.

[15] Zhang, D.J. (2015). Educational Psychology. Beijing: People's Education Press.

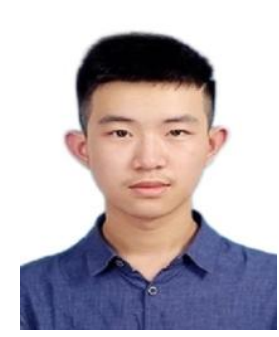

Yefan Ni was born in Zhejiang, China in 1999. He is currently a college student in Zhejiang Ocean University, Zhoushan, China. His research interests include English teaching and pedagogy. 


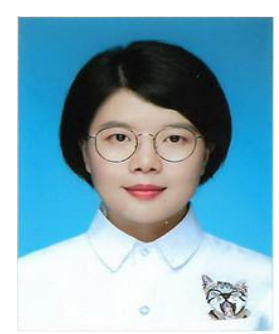

Jingjing Lu is an associate professor in Foreign Language College, Zhejiang Ocean University, Zhoushan, China. She received her M.A. degree in linguistics and applied linguistics from Huazhong University of Science and Technology, China in 2006. Her research interests include cross-culture communication, English teaching and discourse analysis. 